\title{
Cambios en fase y densidad durante la reacción de "conversión" en cementos aluminosos
}

\section{Phase and density changes during the "conversion" reaction of high alumina cement}

\author{
F. P. GLASSER y T. G. JAPPY \\ Departamento de químicas, Universidad de Aberdeen, \\ Meston Walk, Old Aberdeen AB9 2 UE
}

REINO UNIDO

Fecha de recepción: 12-VI-92

\section{RESUMEN}

La base de la reacción de conversión en la cual los cementos aluminosos (HAC - de High Alúmina Cement) desarrollan hidrogranate subsiguiente a su fraguado, está bien establecida y sus características mineralógicas concuerdan con las relaciones de equilibrio de fase en el sistema $\mathrm{CaO}-\mathrm{Al}_{2} \mathrm{O}_{3}-\mathrm{H}_{2} \mathrm{O}$. Una cosa que se entiende más difícilmente es el papel de sílice en la conversión. La sílice se puede convertir en hidrogranate que tiene la fórmula $\mathrm{Ca}_{3} \mathrm{Al}_{2} \mathrm{Si}_{3-x} \mathrm{O}_{12-4 x}(\mathrm{OH})_{4 x}$. Además, la densidad de la fase hidrogranate aumenta rápidamente con la extensión de la sustitución de sílice. Se presentan nomógrafos que demuestran la variación de densidad y del espaciado d de rayos $X$ con la composición. Aunque el HAC contiene relativamente poco $\mathrm{SiO}_{2}$, el examen del cemento aluminoso curado a $85^{\circ} \mathrm{C}$ y con $2,46 \% \mathrm{SiO}_{2}$ (en peso), demuestra que este hidrogranate concentra sílice. Sin embargo, el hierro está presente principalmente como óxido de hierro hidratado amorfo. Se estudian las condiciones que evitan la conversión.

\begin{abstract}
$S U M M A R Y$
The basis of the conversion reaction, in which high alumina cements develop hydrogarnet subsequent to their set, is weel-established and its minaralogical features accord with phase equilibrium relations in the $\mathrm{CaO}-\mathrm{Al}_{2} \mathrm{O}_{3} \mathrm{H}_{2} \mathrm{O}$ system. What is less well understood is the role of silica in the conversion. Silica may substitute into hydrogarnet, which has the formula $\mathrm{Ca}_{3} \mathrm{Al}_{2} \mathrm{Si}_{3-x} \mathrm{O}_{12-4 x}(\mathrm{OH})_{4 x}$. Moreover the density of the hydrogarnet phase increases rapidly with the extent of silica substitution. Nomographs showing the variation of density and $X$-ray $d$ spacing with composition are presented. Although $\mathrm{HAC}$ contains relatively little $\mathrm{SiO}_{2}$, examination of a high alumina cement warm cured at $85^{\circ} \mathrm{C}$ and containing $2.46 \mathrm{wt} \% \mathrm{SiO}_{2}$, shows that this hydrogarnet concentrates silica. Iron is, however, present mainly as amorphous hydrated iron oxide. Implications for cement proportioning to avoid conversion are discussed.
\end{abstract}

\section{INTRODUCCIÓN}

Estudios de relaciones de fase en el sistema CaO- $\mathrm{Al}_{2} \mathrm{O}_{3}-\mathrm{H}_{2} \mathrm{O}$ bajo la presión de 1 bar y a $18^{\circ}-100^{\circ} \mathrm{C}$ revelan que la única fase ternaria estable es $\mathrm{Ca}_{3} \mathrm{Al}_{2}(\mathrm{OH})_{12}$. Sin embargo, esta fase no se puede formar inmediatamente en el proceso de hidratación del cemento; cementos aluminosos tienden a formar $\mathrm{CAH}_{10}$ y $\mathrm{C}_{2} \mathrm{AH}_{8}$ durante el fraguado inicial. Reacciones que ocurren después del fraguado incluyen transformación de hidratos pre-existentes en una fase más estable $\mathrm{Ca}_{3} \mathrm{Al}_{2}(\mathrm{OH})_{12}$ conocida como "conversión". Su producto, $\mathrm{Ca}_{3} \mathrm{Al}_{2}(\mathrm{OH})_{12}$, es una fase relativamente compacta; su relación estructural con el granate de grosularita, un silicato muy compacto, es bien conocida. Como

\section{INTRODUCTION}

Studies of phase relationships in the $\mathrm{CaO}-\mathrm{Al}_{2} \mathrm{O}_{3}-\mathrm{H}_{2} \mathrm{O}$ system at 1 bar pressure and $18^{\circ}-100^{\circ} \mathrm{C}$ disclose that the only stable ternary phase is $\mathrm{Ca}_{3} \mathrm{Al}_{2}(\mathrm{OH})_{12}$. Nevertheless, this phase may not form immediately in the course of cement hydration; calcium aluminate cements tend to form $\mathrm{CAH}_{10}$ and $\mathrm{C}_{2} \mathrm{AH}_{8}$ during initial set. Reactions occurring subsequent to set involve transformation of pre-existing hydrates to the more stable $\mathrm{Ca}_{3} \mathrm{Al}_{2}(\mathrm{OH})_{12}$ phase, are known as "conversion". Its product, $\mathrm{Ca}_{3} \mathrm{Al}_{2}(\mathrm{OH})_{12}$, is a relatively dense phase; its structural relation to grossularite garnet, a close-packed silicate, are well known. Consequently the diminution of solid phase volume occuring during conversion opens up 
consecuencia, la disminución del volumen de la fase sólida que ocurre durante la conversión abre una posibilidad que, a su vez, disminuye la fuerza y aumenta la susceptibilidad de la matriz al ataque químico.

Dada la importancia de la fase granate para la hidratación del cemento, sorprende el hecho de que existan tan pocos datos en la literatura de caracterización a cerca de sus disoluciones sólidas. El propósito de este trabajo es proporcionarlos y estudiar sus consecuencias para la hidratación del cemento aluminoso y sus mezclas con escoria.

\section{CRISTALOQUIMICA DE DISOLUCIONES SÓLIDAS DE HIDROGRANATE}

La hidrogrosularita, $\mathrm{Ca}_{3} \mathrm{Al}_{2}(\mathrm{OH})_{12}$, forma disoluciones sólidas con la grosularita, $\mathrm{Ca}_{3} \mathrm{Al}_{2}\left(\mathrm{SiO}_{4}\right)_{3}$. La fórmula de las disoluciones sólidas es por consiguiente $\mathrm{Ca}_{3} \mathrm{Al}_{2} \mathrm{Si}_{3-\mathrm{x}} \mathrm{O}_{12-4 \mathrm{x}}(\mathrm{OH})_{4 \mathrm{x}}$. La estructura cristalina de disoluciones sólidas de hidrogrosularita está bien establecida, de acuerdo con la naturaleza de la sustitución principal cristalina (1-3), aunque queda la duda sobre la posición precisa de los átomos de $\mathrm{H}$. También ha existido desacuerdo sobre los valores permitidos de $x$ en la fórmula anterior, porque mientras unos la consideraban una disolución sólida (4), otros la encontraban discontinuidades $(5,6)$. Diversos investigadores han examinado la continuidad de las disoluciones sólidas obtenidas a $50^{\circ}-190^{\circ} \mathrm{C}$ y encuentran vacios de miscibilidad donde hay bajo contenido de sílice, cerca de $\mathrm{Ca}_{3} \mathrm{Al}_{2}(\mathrm{OH})_{12}$; estas disoluciones se comentarán en otro trabajo (7). Sin embargo, frecuentemente basta un tratamiento aproximado de datos característicos; en la mayor parte del trabajo que sigue sólo necesitaremos utilizar las composiciones medias de granate.

Tres posibles sustituciones afectan la composición de fase de hidrogranate en cemento aluminoso:

1) Sustitución de $\mathrm{SiO}_{4}^{4-}$ por $4 \mathrm{OH}^{-}$.

2) Sustitución de $\mathrm{Fe}^{3+}$ por $\mathrm{Al}^{3+}$. Esto lleva a otros dos componentes finales de la serie granate, llamados hidroandradita y andradita, $\mathrm{Ca}_{3} \mathrm{Fe}_{2}{ }^{3+}(\mathrm{OH})_{12}$ y $\mathrm{Ca}_{3} \mathrm{Fe}_{2}{ }^{3+}\left(\mathrm{SiO}_{4}\right)_{3}$, respectivamente.

3) Deficiencia de (Al, Fe) en posiciones octaédricas, posiblemente compensadas por sustitución de Si adicional.

\section{CARACTERIZACIÓN A TRAVÉS DE RAYOS X}

Las disoluciones sólidas de H-G, preparadas a $55^{\circ} \mathrm{C}-190^{\circ} \mathrm{C}$ en nuestro laboratorio con reactivos puros, fueron examinadas utilizando rayos $X y$ porosity which, in turn, decreases the strength and increases the susceptibility of the matrix to chemical attack.

Given the importance of the garnet phase to cement hydration, it is surprising that so little characterisation data on its solid solutions are given in the literature. The purpose of this paper is to provide additional data and discuss their implications to high alumina cement hydration and its blends with slag.

\section{CRYSTAL CHEMISTRY OF HYDROGARNET SOLID SOLUTIONS}

Hydrogrossularite, $\mathrm{Ca}_{3} A I_{2}(\mathrm{OH})_{12}$, forms solid solutions with grossularite, $\mathrm{Ca}_{3} \mathrm{Al}_{2}\left(\mathrm{SiO}_{4}\right)_{3}$. The formula of the solid solutions is thus $\mathrm{Ca}_{3} \mathrm{Al}_{2} \mathrm{Si}_{3-x} \mathrm{O}_{12-4 x}(\mathrm{OH})_{4 x}$. The crystal structure of hydrogrossularite solid solutions are well established, as is the nature of the principal crystallochemical substitution (1-3), although doubts persist about the precise location of the $H$ atoms. There has also been disagreement about permissible values of $x$ in the above formula, some workers claiming continuous solid solution (4) others finding discontinuities $(5,6)$. The writers have examined the continuity of the solid solutions obtained at $55^{\circ}-190^{\circ} \mathrm{C}$ and find miscibility gaps at low silica contents, close to $\mathrm{Ca}_{3} \mathrm{Al}_{2}(\mathrm{OH})_{12}$; these will be described elsewhere (7). However, for many purposes an approximate treatment of characterisation data suffices, and in much of what follows we need only to use averaged garnet compositions.

Three possible substitutions affect the composition of the hydrogarnet phase in high alumina cement:

1) Substitution of $\mathrm{SiO}_{4}^{4}$ for $4 \mathrm{OH}^{-}$.

2) Substitution of $\mathrm{Fe}^{3+}$ for $\mathrm{aL}^{3+}$. This leads to two more garnet structured end members, designated hydroandradite and andradite, $\mathrm{Ca}_{3} \mathrm{Fe}_{2}{ }^{3+}(\mathrm{OH})_{12}$ and $\mathrm{Ca}_{3} \mathrm{Fe}_{2}{ }^{3+}\left(\mathrm{SiO}_{4}\right)_{3}$, respectively.

3) Deficiency of (Al, Fe) in octahedral sites, possibly balance by substitution of additional Si.

\section{X-RAY CHARACTERIZATION}

Hydrogrossularite-grossularite solid solutions, prepared at $55^{\circ} \mathrm{C}-190^{\circ} \mathrm{C}$ in our laboratory from pure reactants, were examined by $X$-ray powder 
difracción electrónica de monocristal. Éstos demuestran que la simetría cúbica ideal del granate, la3d, persiste de hidrogrosularita hasta por lo menos $50 \mathrm{~mol} \%$ grosularita, que es el límite aproximado a 1 bar. Siendo éste el caso, los datos de rayos $X$ se tratan para obtener tamaños de unidad de celdilla. Yoder midió el tamaño de la serie grosularita-hidrogrosularita (8) y notó una pequeña desviación negativa con respecto a la ley de Vegard. Nosotros hemos medido preparados sintéticos hechos entre $55^{\circ}-190^{\circ} \mathrm{C}$. La posición de la $(611)$ reflexión fue determinada con el estándar interno de cuarzo y se descubrió que era independiente de la temperatura de síntesis para composiciones específicas. Los resultados en disoluciones sólidas de sílice muestran una pequeña desviación negativa con respecto a espaciado d ideal. Parece que no se han dado exactas medidas del tamaño de unidad de celdilla de granates para la unión hidrogrosularitahidroandradita, pero sus tamaños varían entre $12,56 \AA$ y $12,74 \AA$ A respectivamente, y de esa manera no son demasiado diferentes de las variaciones que produce la sustitución de sílice. Del mismo modo, la diferencia en dimensión de celdilla entre grosularita y andradita, 11,84 Å y $12,02 \AA$ respectivamente, es relativamente pequeña.

Por lo tanto la Fig. 1 muestra la representación gráfica calculada de las dimensiones de celdilla, sin tomar en consideración pequeñas desviaciones de la ley de Vegard que quizá aparezcan de la conjunción de mecanismos 1,2 y 3 . Se puede ver que, si no se tiene en cuenta la sustitución de hierro, podría introducirse un error sistemático en la estimación de la composición de granate en el granate del cemento aluminoso. Sin embargo, la magnitud del error se reduce por dos factores. Uno es la baja sensibilidad del tamaño de celdilla a la sustitución de hierro. Si, por ejemplo, $10 \%$ de una disolución sólida de andradita-hidroandradita ocurriera en grosularita-hidrogrosularita, pero no se tomará en consideración en la interpretación, se obtendría un $4 \%$ de sobreestimación del contenido de sílice del granate. La segunda razón y la más importante es que el hierro, en la práctica, es rechazado por hidrogranate; la mayor parte de hierro aparece en cemento aluminoso curado como un precipitado amorfo.

\section{MICROSCOPÍA Y ANÁLISIS ELECTRÓNICOS}

Dada las limitaciones de la difracción de rayos $\mathrm{X}$, el uso más importante de microscopía electrónica fue como un instrumento analítico, para determinar composiciones de granate. Los análisis se hicieron utilizando un microscopio JEOL 2000EX TEMSCAN, equipado con un analizador de rayos $X$ LINK 10000 EDS. Las muestras se trataron con baño de carbón, para su and single crystal electron diffraction. These show that the ideal cubic garnet symmetry, la3d, persists from hydrogrossularite up to at least 50 mol \% grossularite, which is the approximate synthesis limit at 1 bar. This being so, the $X$-ray powder data are readily treated to obtain unit cell sizes. The unit cell size of the grossularitehydrogrossularite series were measured by Yoder (8) who reported a slight negative deviation from Vegard's law. We have maesured synthetic prepartions made in the range $55^{\circ}-190^{\circ} \mathrm{C}$. The position of the (611) reflection was determined against a quartz internal standard and found to be independent of synthesis temperature for a specific composition. The results on siliceous solid solutions show a slight negative deviation of $d$ spacings from ideality. No accurate unit cell size measurements seem to have been reported for garnets on the join hydrogrossularite-

hydroandradite, but their unit cell sizes range between $12.56 \AA$ and $12.74 \AA$ respectively. and thus do not differ much relative to the variations resulting from silica substitution. Likewise, the difference in cell dimension between grossularite and andradite, $11.84 \AA$ and $12.02 \AA$ respectively, is relatively small.

Therefore, a calculated plot of the cell dimensions, neglecting slight departures from Vegard's law perhaps arising from a conjunction of mechanisms 1, 2 and 3, is shown in Fig. 1. It can be seen that estimating the garnet composition of, say, garnet in high alumina cement could introduce a systematic error unless iron substitution is taken into account. However, the magnitude of the error is reduced by two factors. One is the low sensitivity of the unit cell size to iron substitution. If, for example, $10 \%$ of an andraditehydroandradite solid solution occurred in grossularite-hydrogrossularite, but is neglected in the interpretation, an overestimate of the silicon content of the garnet of about $4 \%$ will result. The second and most important reason is that iron is, in practice, rejected by the hydrogarnet; most of the iron appears in warm cured aluminous cement as an amorphous precipitate.

\section{ELECTRON MICROSCOPY AND ANALYSIS}

Given the limitations of $X$-ray diffraction, the most important use of electron microscopy was as an analytical tool, to determine garnet compositions. The analyses were made using a JEOL 2000EX TEMSCAN microscope equipped with a LINK 10000 EDS X-ray analyser. Specimens were dispersed on carbon grids coated for analysis. Calibration standards included a number of 


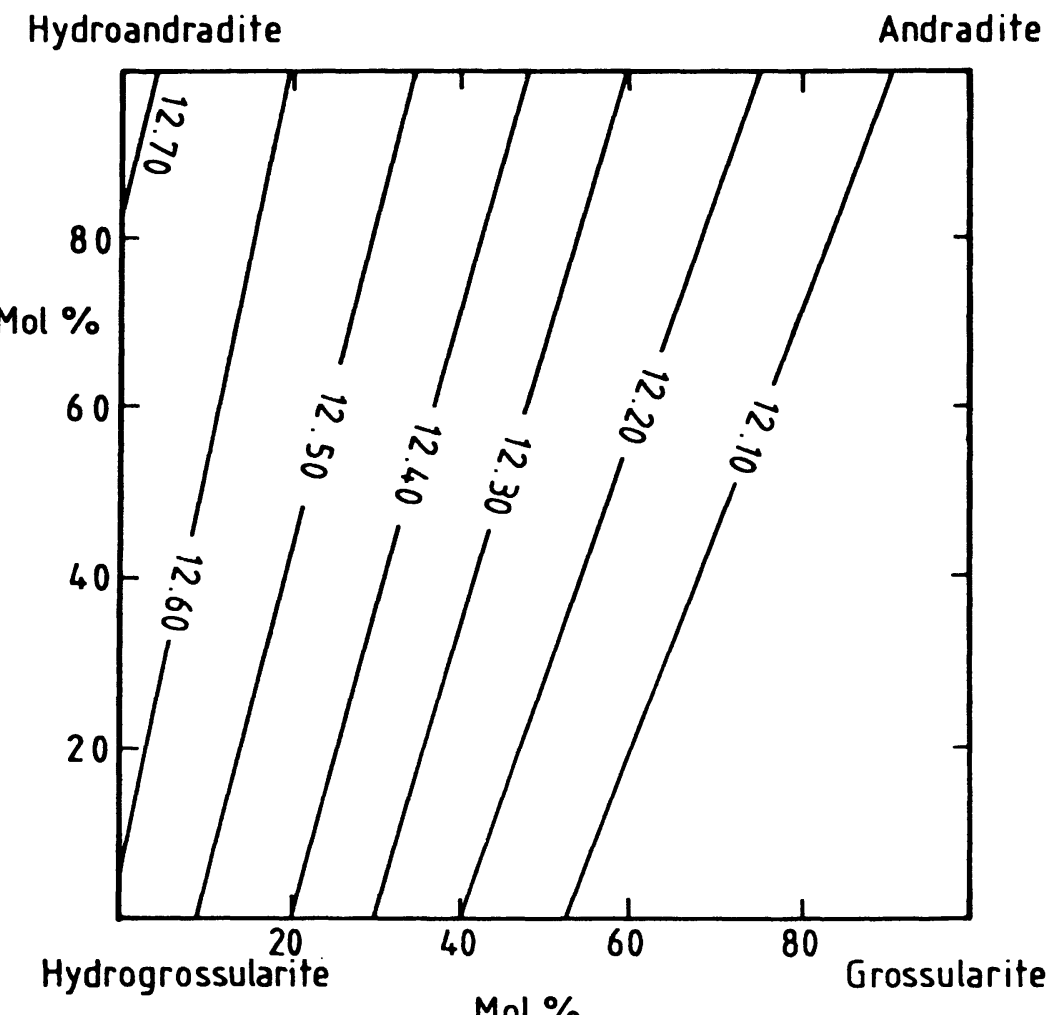

Fig. 1.-Espaciados d de rayos $X$, en $A$ calculados para granates del grupo upgrandite. La ley de Vagard se supone y no se tienen en cuenta los vacíos de miscibilidad cercanos a la hidrogrosularita.

Fig. 1.- Calculated $X$-ray $d$ spacings, in $A$ for ugrandite group garnets. Vegard's law is assumed and no account is taken of miscibility gaps close to hydrogrossularite.

TABLA 1 TABLE 1

Curado en cementos aluminosos comerciales (Curing experiment on comercial high alumina cement)

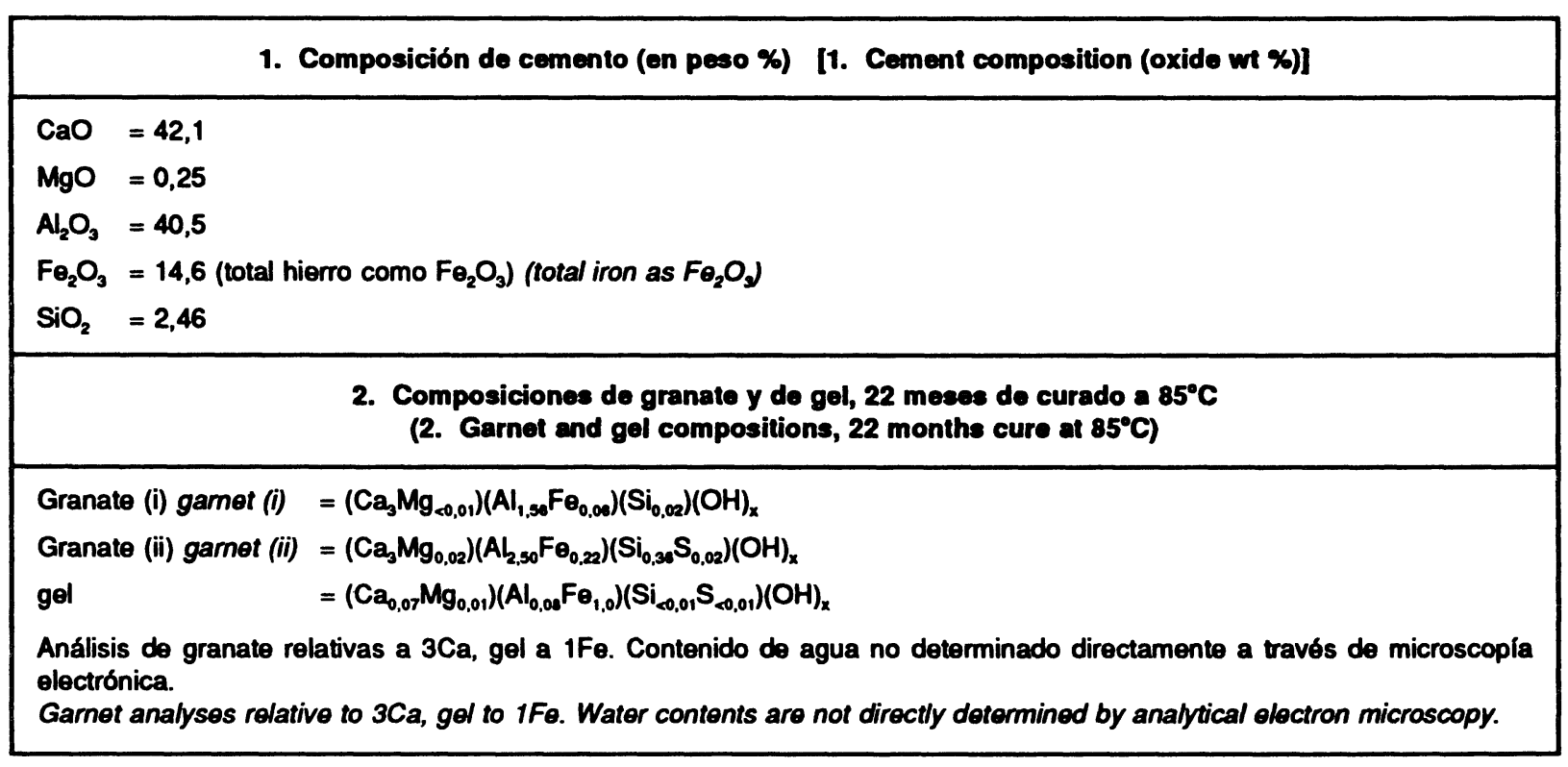


análisis. Los patrones para la calibración incluían un número de aluminatos y silicatos cálcicos puros y $\mathrm{C}_{3} \mathrm{AH}_{6}$ sintético.

\section{COMPOSICIÓN DEL HIDROGRANATE ESTABLE EN EL HAC}

Un HAC comercial se mezcló con agua a $a / c=0,5 y$, después de corto curado, se desenmoldó y curó durante 21 meses a $85^{\circ} \mathrm{C}$ para obtener una composición estable. La tabla 1 da datos sobre el cemento utilizado y sobre la composición del granate encontrada a través de microscopía electrónica. Esta determinación fue interferida por la presencia de cierta cantidad de gel, cuya composición se muestra en análisis (iii). Sin embargo, se distinguen claramente varias tendencias. Primero, ocurren dos fases de granate. Esto está confirmado por la difracción de rayos $X$, que da aparentemente "reflexiones split", es decir dos tipos de reflexiones con espaciados muy cercanos, donde ambos son atribuibles a hidrogranate. Un tipo tiene espaciados $d$ de rayos $X$ cerca del $\mathrm{C}_{3} \mathrm{AH}_{6}$ puro mientras el segundo tipo está desplazado debido a un contenido considerable de silicio; el hierro determinado por microscopia electrónica es insignificante. El alto contenido de hierro que se indica en algunos análisis a veces se debe, indudablemente, a la contaminación de gel. Sin embargo, una de las fases de granate contiene Si apreciable, del orden de 10-12 mol \% de grosularita. Asimismo, a pesar del bajo contenido de $\mathrm{SiO}_{2}$ del cemento, sólo 2,46 \%, mucho de este Si se concentra en la fase granate. El hidrogranate que contiene sílice se forma con exclusión de gehlenita hidratada.

\section{FASE GEL}

El óxido de hierro originalmente presente en la escoria de cemento aparece principalmente como un óxido de hierro amorfo, presumiblemente hidratado. Es amorfo para la difracción de rayos $X$ y no da difracción de electrones. Aunque el gel está descrito como "óxido de hierro", aparentemente incluye cierta cantidad de Al y un poco de $\mathrm{Ca}, \mathrm{Mg}$ y Si. No obstante, las cantidades de estos elementos son tan pocas que sugieren que, como primera aproximación, el gel es básicamente óxido de hierro hidratado. La presencia de gel rico en hierro ayuda a explicar porqué el granate contiene poco hierro.

\section{DISCUSIÓN}

George (9) ha relacionado la temperatura de curado con la densidad de las pastas de cemento hidratado aluminoso, como se ven en la tabla 2. La interpretación de estos datos es la siguiente: el curado en caliente produce una pasta densa con phase-pure calcium aluminates and silicates, including synthetic $\mathrm{C}_{3} A \mathrm{H}_{6}$.

\section{STEADY-STATE COMPOSITION OF HYDROGARNET IN HAC}

A commercial HAC was mixed with water to $w / s=0.5$ and, after brief cure, was demoulded and cured for 21 months at $85^{\circ} \mathrm{C}$ to obtain a steady-state composition. Table 1 gives data on the cement used and on the garnet composition found by analytical electron microscopy. This determination was handicapped by the presence of some gel, the composition of which is show in analysis (iii). Nevertheless, several trends are clear. Firstly, two garnet phases occur. This is confirmed by $X$-ray diffraction, which gives apparently "split reflections" i.e. two closelyspaced sets of reflections, both of which are attributable to hydrogarnet. One set has $X$-ray $d$ spacings close to pure $C_{3} A H_{6}$ while the second set is shifted due to an appreciable silicon content; iron determined by analytical electron microscopy, is negligible. The high iron content occasionally indicated in analyses is undoubtedly due to gel contamination. Nevertheless, one of the garnet phases contains appreciable Si, on the order of 10-12 mol \% glossularite. Thus, despite the low $\mathrm{SiO}_{2}$ content of the cement, only $2.46 \%$, much of this Si concentrates in the garnet phase. Silica-containing hydrogarnet forms to the exclusion of gehlenite hydrate.

\section{GEL PHASE}

The iron oxide originally present in the cement clinker mainly occurs as amorphous, presumably hydrated, iron oxide. It is amorphous to X-ray diffraction and does not give electron diffractions. Although the gel is described as "iron oxide", it apparently includes some $\mathrm{Al}$ and a little $\mathrm{Ca}, \mathrm{Mg}$ and Si. However, the totals of these elements are so low as to suggest that as a first approximation the $\mathrm{gel}$ is essentially hydrated iron oxide. The presence of iron-rich gel helps explain why the garnet is iron-poor.

\section{DISCUSSION}

George (9) has related cure temperature to the density of hydrated high alumina cement pastes, as shown in Table 2. The interpretation of these data is as follows: warm cure produces a dense paste with little porosity. However, if the paste is 


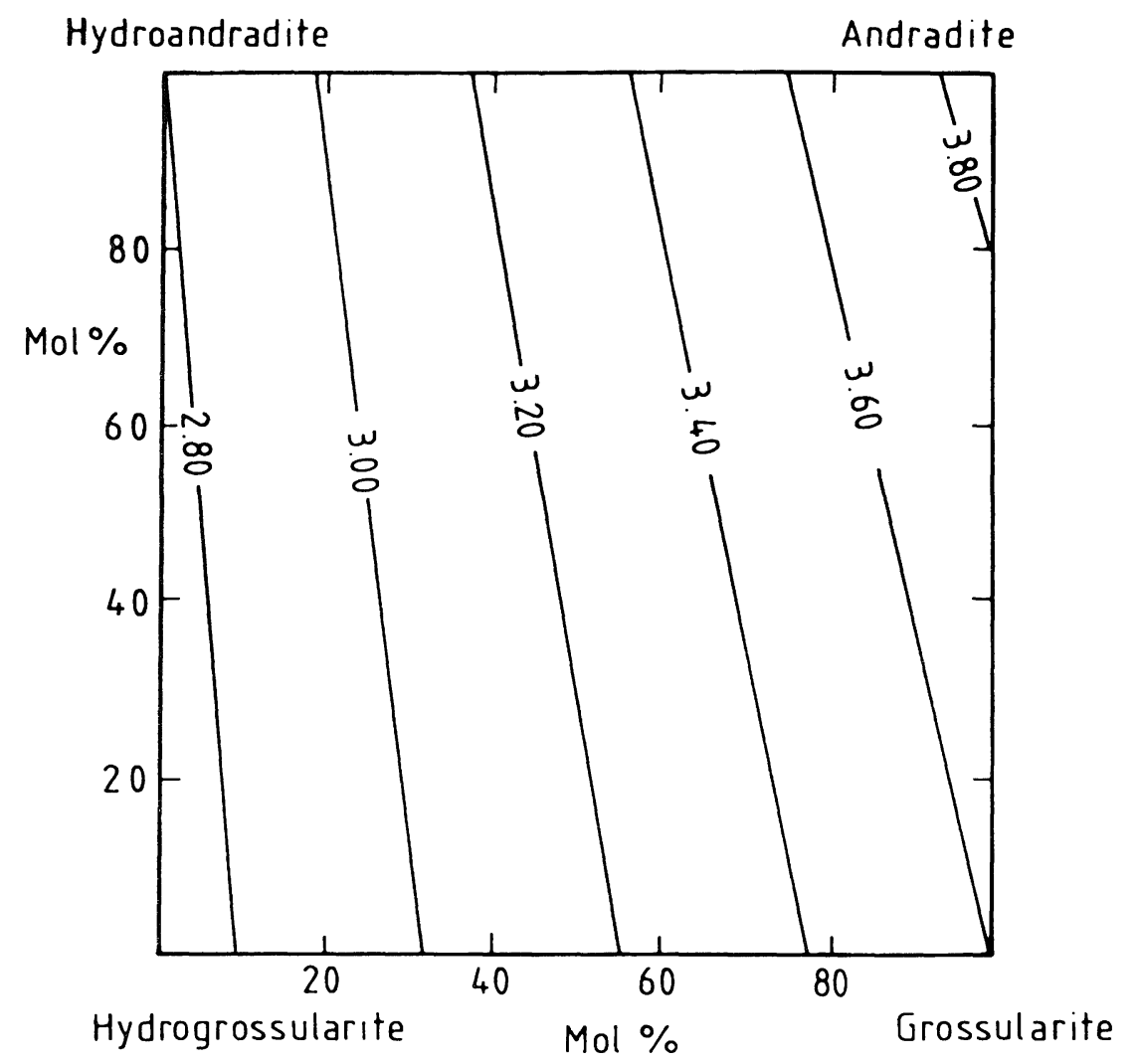

Fig. 2.-Densidad calculada, en $\mathrm{g} \cdot \mathrm{cm}^{-3}$, de granates del grupo upgrandite.

Fig. 2.-Calculated density, in $\mathrm{g} \cdot \mathrm{cm}^{-3}$, of ugrandite group garnets.

TABLA 2 TABLE 2

Densidades de productos de hidratación de pastas de cemento aluminoso (Densities of HAC phase assemblages)

\begin{tabular}{|c|c|c|c|}
\hline \multirow[b]{2}{*}{$\begin{array}{l}\text { Temperatura curado }{ }^{\circ} \mathrm{C} \\
\text { (Cure temp. }{ }^{\circ} \mathrm{C} \text { ) }\end{array}$} & \multirow[b]{2}{*}{$\begin{array}{l}\text { Reacción de hidratación } \\
\text { (Hydration reaction) }\end{array}$} & \multicolumn{2}{|c|}{ Densidad, $\mathrm{g} / \mathrm{cm}^{3}$ de: (Density, $\mathrm{g} / \mathrm{cm}^{3}$ of:) } \\
\hline & & $\begin{array}{c}\text { Productos sólidos } \\
\text { hidratados } \\
\text { (Solid hydrate } \\
\text { product) }\end{array}$ & $\begin{array}{c}\text { Pasta típica } \\
\text { (Typical paste) }\end{array}$ \\
\hline $20^{\circ}$ & $\mathrm{CA}+10 \mathrm{H} \rightarrow \mathrm{CAH}_{10}$ & 1,70 & $\sim 1,6$ \\
\hline $50^{\circ}$ & $\mathrm{CA}+4 \mathrm{H} \rightarrow 1 / 3 \mathrm{C}_{3} \mathrm{AH}_{6}+2 / 3 \mathrm{AH}_{3}$ & 2,45 & $\sim 2,1$ \\
\hline
\end{tabular}

Nota: el curado a $20^{\circ} \mathrm{C}$ es el habitual para compuestos no convertidos, mientras el curado de $50^{\circ} \mathrm{C}$ es representativo de los completamente convertidos.

Note: $20^{\circ} \mathrm{C}$ cure is typical of unconverted product while $50^{\circ} \mathrm{C}$ cure is representative of fully converted product. 
poca porosidad. Sin embargo, si la pasta se pone inicialmente a una temperatura tan baja que el producto hidratado inicial tiene baja densidad, también se obtiene buena resistencia. Pero si la pasta de baja densidad se cura posteriormente a temperaturas más altas, $55^{\circ}-85^{\circ} \mathrm{C}$ en este caso, la fracción total del volumen ocupada por hidratos disminuye debido a la formación de granate y la resistencia también disminuye.

Los datos presentados en la Fig. 2 demuestran que la densidad de la fase hidrogranate se aumentará rápidamente en función de sus contenidos de sílice y hierro. En pastas no convertidas, la sílice está presente quizás como C-S- $\mathrm{H}$, de densidad $-2,2-2,3 \mathrm{~cm}^{-3}$. Pero si la sílice entra en la estructura del granate durante la conversión, ella no sólo tiende a aumentar el contenido de hidrogranate, sino también aumenta la densidad del hidrogranate producido. Los aumentos en la cantidad de granate y el contraste de densidad producido tienden a realzar la caída en resistencia que ocurre como consecuencia de la conversión.

Los datos revelan que el Si en cementos aluminosos está claramente repartido en el hidrogranate después de un largo curado en caliente. Si este comportamiento es representativo de las reacciones que ocurren durante la conversión a temperatura baja ( $y$ no está comprobado que esto sea así), el efecto de sustitución de la sílice es aumentar la densidad media del hidrogranate en aproximadamente 0,1 $\mathrm{g} / \mathrm{cm}^{3}$, de $\sim 2,72 \mathrm{~cm}^{-3}\left(\mathrm{C}_{3} \mathrm{AH}_{6}\right.$ puro) a $2,82 \mathrm{~g} / \mathrm{cm}^{3}$ para el granate silíceo que es el producto observado. El hierro, por otro lado, tiende a persistir como gel con un pequeño contenido de $\mathrm{Al}$, etc.; relativamente poco hierro entra en la estructura del granate bajo estas condiciones de curado, así que el contenido de hierro en cemento no influye demasiado en el cambio del volumen específico que ocurre durante la conversión.

Esta existencia de dos fases de granate en el producto de HAC curado en caliente es importante para el análisis. La fase de granate en HAC no necesariamente será homogénea, y su composición puede reflejarse con la aparición de vacíos de miscibilidad en el sistema. Los datos de espectroscopía infrarroja y análisis térmico para estos granates se describen on (10).

Estos datos son también muy importantes para producción y uso del cemento. Se ha notado la tendencia de la sílice, y en menor grado del hierro, a aumentar la densidad de la fase del granate y como consecuencia a cambiar el volumen en las reacciones de conversión. Procesos nuevos que pretenden evitar la conversión tienen como objetivo la rápida reacción del producto de la hidratación del cemento con agentes de mezcla que contienen initially set at low temperature, such that the initial hydrate product has low density, good strength is also obtained. But if a low density paste is subsequently cured at higher temperatures, $55^{\circ}-85^{\circ} \mathrm{C}$ in this instance, the total fraction of the volume occupied by hydrates decreases owing to garnet formation and strength also decreases.

The data presented in Fig. 2 show that the density of the hydrogarnet phase will increase rapidly as functions of its silica and iron contents. In unconverted pastes, silica is present perhaps as C-S-H, density - 2.2-2.3 $\mathrm{cm}^{-3}$. But if silica enters the garnet structure during conversion, not only does it tend to increase the amount of hydrogarnet, but it also increases the density of the resulting hydrogarnet. Increases in the amount of garnet and the resulting density contrast tend to enhance the drop in strength arising as a consequence of conversion.

The data disclose that Si in high alumina cements is strongly partitioned into hydrogarnet following prolonged warm cure. If this behavior is representative of reactions occurring during conversion at lower temperature (and it is not proven that this is the case), the effect of silica substitution is to raise the mean density of the hydrogarnet, by about $0.1 \mathrm{~g} / \mathrm{cm}^{3}$, from -2.72 $\mathrm{g} / \mathrm{cm}^{3}$ (pure $C_{3} A_{6}$ ) to $2.82 \mathrm{~g} / \mathrm{cm}^{3}$ for the siliceous garnet which is the observed product. Iron, on the other hand, tends to persist as a gel containing minor Al, etc.; relatively little iron enters the garnet structures under these conditions of cure so the change in specific volume arising during conversion is not much influenced by the iron content of the cement.

This occurrence of two garnet phases in warm cured HAC product has implications to analysis. The garnet phase in HAC will not necessarily be homogeneous and its composition may reflect the occurrence of miscibility gaps in the system. Infrared spectra and thermal analysis data for these complex garnets will be described elsewhere (10).

The data also have implications to cement manufacture and use. The tendency of silicon and, to a lesser extent iron, to increase the density and amount of the garnet phase and hence the change in volume attending conversion reactions have been noted. Newer processes aimed at avoiding conversion have as their objective rapid reaction of cement hydration product with silica-containing blending agents to eliminate phases susceptible to conversion, 
sílice para eliminar fases susceptibles, por ejemplo $\mathrm{CAH}_{10}, \mathrm{C}_{2} \mathrm{AH}_{8}$. Esto se puede conseguir añadiendo escoria de alto horno, cuyo principal producto de reacción es muchas veces gehlenita hidratada. Sin embargo, la proporción molar de Ca:Al:Si en la gehlenita hidratada no es muy diferente de la proporción del hidrogranate silíceo con $\mathrm{Al} / \mathrm{Si}=1,0$ y el balance mineralógico logrado en la mezcla de escoria-HAC podría ser bastante similar a la composición de escoria y la proporción cemento:escoria. De este modo, si se quiere evitar y no sólo aplazar la conversión, se deben tener en cuenta los potenciales balances de las fases hidratadas; se sugiere que la composición, cantidad y reactividad de la escoria podrían ser decisivas si la capacidad de conversión ha de ser eliminada.

\section{AGRADECIMIENTO}

Este trabajo se realizó con el apoyo de la Comisión de las Comunidades Europeas y del Departamento de Medio Ambiente del Reino Unido. Los resultados de este trabajo se pueden utilizar en la política gubernamental, pero las opiniones expresadas en este trabajo no necesariamente representan la política del Gobierno. e.g. $C A H_{10}, C_{2} A H_{8}$. This may be achieved by adding blast furnace slag, the principal reaction product of whinch is often gehlenite hydrate. However, the molar ratio of Ca:Al:Si in gehlenite hydrate is not greatly different from that of a siliceous hydrogarnet with $\mathrm{Al} / \mathrm{Si}=1.0$ and the resulting mineralogical balance achieved in a slag-HAC blend could be quite sensitive to slag composition and cement: slag ratio. Thus the potential phase balances of the hydrate assemblages needs to be assessed if conversion is to be avoided rather than just postponed; it is suggested that the composition, amount and reactivity of the slag could be crucial if the potential for conversion is to be eliminated.

\section{ACKNOWLEDGEMENT}

This work was undertaken with the support of the Commission of the European Communities and of the U.K. Department of the Environment. The results of this work may be used in Government policy, but the views expressed in this paper do not necessarily represent Government policy.

\section{BIBLIOGRAFÍA}

\section{REFERENCES}

(1) E. PASSAGLIA and R. RINALDI: "Katoite, a New Member of the $\mathrm{Ca}_{3} \mathrm{Al}_{2}\left(\mathrm{SiO}_{4}\right)_{3}-\mathrm{Ca}_{3} \mathrm{Al}_{2}(\mathrm{OH})_{12}$ Series and a New Nomenclature for the Hydrogrossularite Series of Minerals" Bull. Mineral., Vol. 107, p. 605-618 (1984).

(2) R. BASO, A. DELLA GIUSTA and L. ZEFIRO: "Crystal Structure Refinement of Plazolite, a Highly Hydrated Natural Hydrogrossular". Neues Jahr. Miner. Mh., p. 251-258 (1983).

(3) M. SACERDOTI and E. PASAGLIA: "The Crystal Structure of Katoite and Implications Whithin the Hydrogrossular Group of Minerals" Bull. Mineral, Vol. 108, p. 1-8 (1985).

(4) E. P. FLINT, et al.: "Studies of Gaarnet-Hydrogarnet Series" Jour. Res. Nat. Bureau Stand (USA) vol. 26, p. 14-33 (1941).

(5) T. SHUJI: " $\mathrm{Ca}_{3} \mathrm{Al}_{2}\left(\mathrm{SiO}_{4}\right)_{3}-\mathrm{Ca}_{3} \mathrm{Al}_{2}\left(\mathrm{ZO}_{4} \mathrm{H}_{4}\right)_{3}$ Series Garnet: Composition and Stability" Jour. Mineral. Soc. Japan Vol. 11, p. $359-372$ (1974).

(6) R. N. EDMUNDS and A. J. MAJUMDAR: "The Hydration of Mixtures of Monocalcium Aluminate and Blastfurnace Slag" Cement Concr. Res. Vol. 19, p. 779-782 (1989).

(7) T. G. JAPPY ad F. P. GLASSER: "Synthesis and Stability of Silica-substituted Hydrogarnet, $\mathrm{Ca}_{3} \mathrm{Al}_{2} \mathrm{Si}_{3-\mathrm{x}} \mathrm{O}_{12-4 x}(\mathrm{OJ})_{4 x}$ " Advances in Cement Res. Vol. 4, p. 1-8 (1991-2).

(8) H. S. Yoder: "Stability Relations of Grossularite" Jour. Geol. Vol. 58, p. 221-253 (1950).

(9) C. M. GEORGE: "Manufacture and Performance of Aluminous Cement: a New Perspective pp. 181-221 in "Calcium Aluminate Cements" (ed., R.J. Mangabhai) E. \& F. Spon (1990) ISBN O 419152008 (HB) pp. $380+$ X.

(10) T. G. JAPPY MSc Thesis: "Silica Substituted Calcium Aluminate Hydrate Garnets" University of Aberdeen, 1992. 